were studying in colleges, they were not targeted. At the same time, according to our researches, the nature of work in preschool educational establishments presents to the nurse essentially other professional requirements. We took into account the peculiarities of the psychological training of future nurses in medical colleges.

The modern regulatory requirements for the activity of a nursing school in pre-school educational institutions are taken into account. It is not enough for them to have only special training, the nurses should be able to shape their psychological competence (in accordance with the peculiarities of work in this institution). The author analyzed the peculiarities of nursing activities for a nurse, ranging from the birth of this profession to modern nursing activities for a nurse's institute in particular.

Key words: health; nurses of pre-school educational institutions; competence; communication; psychological competence.

УДК 159.9- 051

DOI: https://doi.org/10.35619/prap_rv.vi12.45

О. Д. ГЛАВІНСЬКА, Л. О. НОВІК

\title{
УСВІДОМЛЕННЯ МАЙБУТНІМИ ПСИХОЛОГАМИ ПРОФЕСІЙНОЇ НАЛЕЖНОСТІ
}

У статті розглядається проблема професійного становлення майбутніх психологів. Досліджується феномен уявлення про професію як складний особистісний практичний механізм, який є показником суб'єктивного досвіду, компонентом професійної самосвідомості. Отримані у ході дослідження результати вказують на необхідність здійснення психологічних впливів, спрямованих на розвиток професійних підструктур самосвідомості, а також створення відповідних психологічних умов для оптимізачії процесу формування особистіснозрілого фахівия в умовах навчання у закладах вищої освіти.

Ключові слова: професійне становлення, професійне самовизначення, професійна свідомість, уявлення про професію, майбутні психологи.

Статья посвящена проблеме готовности будущих психологов $к$ профессиональному самоопределению и профессиональному становлению. Исследуется феномен представления о профессии как личностный практический механизм, который выступает показателем субъективного опыта, компонентом профессионального сознания. Полученные в ходе исследования результаты свидетельствуют о необходимости психологического влияния, направленного на развитие профессиональных подструктур сознания, а также создания соответствуюших психологических условий для оптимизации процесса формирования личностно зрелого специалиста 8 условиях обучения в учреждениях высшего образования.

Ключевые слова: профессиональное становлени, профессиональное самоопределение, профессиональное сознание, представление о профессии, будущие психологи.

Постановка наукової проблеми та ії значення. Головними сферами життєдіяльності студентів $\epsilon$ професійне навчання, особистісне зростання та самоствердження, розвиток інтелектуального потенціалу, духовне збагачення, моральне, естетичне та фізичне самовдосконалення. Цей період особистісного становлення характеризується оволодінням усім різноманіттям соціальних ролей дорослої людини: отримання права вибору, набуття певної юридичної та економічної відповідальності, можливість включення в усі види соціальної активності, здобуття вищої освіти та опанування професії. Найважливішою детермінантою ефективності професійної діяльності вважається професійна свідомість фахівця - психологічне утворення, в якому інтегруються професійні цінності, науково-теоретичні знання, програми професійних дій, а також знання людини про себе як про представника певної професії. Саме професійна свідомість акумулює всі ці аспекти, рівні, функції у практичній та теоретичній професійній діяльності майбутнього фахівця.

Професійна належність $€$ результатом тривалого процесу професійного розвитку, який базується на глибокому пізнанні себе, розумінні та усвідомленні вимог бажаної майбутньої професії. При цьому важливим аспектом результативної складової професійної належності є сформованість рівня професійних домагань та адекватна самооцінка. Цей функціональний зв'язок демонструє прагнення в обраній професії досягнути цілей певної складності. Можна стверджувати, що професійні домагання являються якісною характеристикою професійної належності і невід'ємно пов'язані $з$ динамічними показниками успіху як рушійного особистісного еквіваленту. Необхідність 
формування високого рівня професійної свідомості майбутніх психологів обумовлена суспільною потребою у професіоналізмі та престижністю професії у системі освіти.

Аналіз останніх досліджень із зазначеної проблеми. У психологічній науці питаннями самовизначення особистості займались К. Абульханова-Славська, М. Боришевський, Г. Костюк, О. Леонтьєв, С. Максименко, А. Маслоу, К. Роджерс, С. Рубінштейн та інші. Предметом уваги цих дослідників стали сутність та джерела активності особистості, особливості життєвого самовизначенння та самореалізації. Особливості професійного самовизначення, його складові та етапи розкриті у роботах Ж. Вірної, Ю. Гільбуха, О. Голомштока, Е. Зеєра, Є. Клімова, І. Манохи, А. Маркової, В. Моргуна, С. Павлютенкова, В. Синявського, С. Чистякової, Б. Федоришина, П. Шавіра та інших. Узагальнюючи дослідження цих вчених, можна констатувати, що професійне самовизначення - це тривалий процес, що є провідною складовою становлення особистості фахівця, його професійної свідомості та самосвідомості.

Значний інтерес для розуміння розвитку професійної свідомості майбутніх психологів становлять дослідження вітчизняних вчених М. Боришевського, О. Бондарчука, М. Варбана, I. Вачкова, Н. Волянка, А. Деркача, Є. Клімова, В. Козієва, А. Маркової, Л. Мітіної, О. Москаленко, В. Панка, Н. Пов'якель, Н. Чепелевої, Н. Шевченко та ін. Категорією «професійна свідомість», як стверджує Н.Ф.Шевченко, можна охопити всі прояви свідомості особистості, які пов'язуються з іiі професійною діяльністю і визначаються багатьма чинниками: місцем професії в професійній структурі суспільства; ставленням самої особистості до професії, до ії представників та до себе як представника професії, усвідомленням значущості професії для суспільства; рівнем здобутих професійних знань та вмінь, здійсненням самоаналізу стосовно перспектив власного професійного зростання; сформованими професійними ідеалами, уявленнями про еталон професіонала; рівнем розвитку професійних здібностей та якостей, а також осмисленням власних професійно вагомих якостей; професійними досягненнями.

Важливими складовими професійної свідомості та самосвідомості особистості виступають уявлення про професію (Ю. Долинська, С. Максименко, В. Панок, Н. Пов'якель, В. Рибалка, Н. Чепелєва, Н. Шевченко та ін.). Уявлення про професію - це певний тип соціальних уявлень особистості, які переважно утворюються в результаті трансформації іiі індивідуальних образів, установок і соціальних стереотипів щодо конкретного виду професійної діяльності [5, с. 86]. Уявлення про професію виконує ряд функцій, найважливішою 3 яких $є$ самовираження, що забезпечує зміцнення «Я-концепції» та захист власного «Я» від критики зі сторони нефахівців. Професійні уявлення сприяють адаптації особистості до професійного середовища та розширюють можливості професійної діяльності.

Мета статті - теоретично обгрунтувати та емпірично вивчити зміст та особливості уявлень про майбутню професію у студентів-психологів

Методи дослідження. Для дослідження особливостей уявлень про професію у майбутніх психологів було використано методики «Хто Я?» М. Куна і Т. Макпартленда та «Особисті професійні плани» Є.О. Клімова. У дослідженні взяли участь 23 студенти першого курсу та 20 п'ятикурсників, які здобувають фах психолога у Рівненському державному гуманітарному університеті.

Виклад основного матеріалу і обгрунтування отриманих результатів дослідження. У сучасній психологічній науці професійна свідомість трактується як найважливіша категорія, яка реально відображає суть процесу професійного становлення й розвитку фахівця, і саме вона $\epsilon$ основною умовою якісної професійної діяльності і забезпечує цілісність професійної культури фахівця [8].

Професійна самосвідомість у дослідженнях О.Туриніної розглядається як сукупність знань про власні особливості, наявні професійні здібності та інтереси. Констатація особистістю успіхів і невдач власної професійної або навчальної діяльності є чинником коригування «Я - образу», самооцінки, рівня домагань та професійної самосвідомості в цілому [7]. Адекватне уявлення про себе дозволяє розширити сферу можливостей особистості, перетворити невдачі в успіхи, виявити нові здібності і таланти. У процесі навчально-професійної діяльності особистість набуває і розвиває уявлення про майбутню професію і свої можливості в ній. Спочатку у свідомості виникає ідеальний «Я-образ» (еталон особистості-професіонала), потім 3'являється суперечність між реальним «Яобразом» і еталоном особистості-професіонала. У результаті вирішення суперечності з'являється $\mathrm{i}$ розвивається «Я-образ» особистості як суб’єкта майбутньої професійної діяльності. Розвиваючись як суб'єкт професійної діяльності і формуючи ставлення до себе (як до професіонала), людина формується як особистість [4, с. 287].

Творче самовизначення себе як професіонала, на думку А. Маркової, відбувається упродовж професійного навчання [3]. Саме на етапі вузівського навчання включення студентів у навчально- 
професійну діяльність сприяє формуванню системи їх професійних знань, умінь, навичок, елементів професійного мислення і пам'яті, з одного боку, і розвитку адекватної професійної поведінки, з іншого. Даний етап характеризується формуванням уявлення про себе та ставлення до себе як суб'єкта професійної діяльності, які обумовлюють якісні зміни у структурі професійної самосвідомості. Образи та уявлення про професію не виникають самі по собі, а являються продуктом самопізнання особистості. Неможливо розглядати професійні уявлення як окремий компонент професійної самосвідомості, а вони вимагають ії цілісного дослідження у системі професійних знань, навичок, умінь, професійної готовності та адаптованості, усвідомленості своїх можливостей, характерних особливостей, визначеності професійної ролі та позиції суб'єкта діяльності тощо. Тому уявлення про обрану професію майбутніх психологів можна розглядати як різновид соціальних уявлень, які є результатом отримання психологічних знань, професійних умінь та навичок у ході спеціалізованої підготовки, перетворення типових та індивідуальних образів професії психолога, а також усвідомлення себе як майбутнього психолога-фахівця.

Зважаючи на результати емпіричних досліджень І. Сгорової [1], К. Міхно [5], О. Семенової [6], можна стверджувати, що вже на початкових етапах навчання уявлення першокурсників про психологію як свою майбутню професію суттєво змінюються, формуються засади професійного погляду на світ, на інших людей, на власне місце у світі. По мірі навчання відбувається переоцінка різних аспектів діяльності психолога; уявлення студентів-психологів про професію стають більш цілісними й адекватними.

Професійне самовизначення розглядається як вибір і реалізація способу взаємодії 3 оточуючим світом і пошуком сенсу у цій діяльності. Сучасному суспільстві потрібен професіонал, який знає свою справу, може самостійно приймати рішення, відповідати за них, за себе, за інших. Важливим фактором, який визначає сьогодні формування професійного самовизначення, $\epsilon$ комерціалізація відносин. Відбувається заміна професійної кар'єри на комерційну, що не дає можливості людині відбутися в професійному сенсі. Перехідний стан економіки зумовив відхилення у системі професійних цінностей: сучасна молодь з ії особистісними особливостями, яка вступає у ринкові відносини, прагне добитися матеріального благополуччя. Необхідність виживання змушує зрадити своє покликання, тобто існує мотивація оволодіння прибутковою професією, але часто в молодої людини немає необхідних для цього якостей. Спостерігається також протиріччя між мотивацією вибору професії та можливістю оволодіти нею.

Плануючи емпіричне дослідження, ми виходили з того, що образи та уявлення про професію трансформуються, доповнюються, розширюються, уточнюються під впливом професійних знань, навичок, умінь, професійної готовності та адаптованості, усвідомленості своїх можливостей, характерних особливостей, визначеності професійної ролі та позиції суб'єкта діяльності тощо. Дослідженням було охоплено 43 студенти Рівненського державного гуманітарного університету, 3 них 23 першокурсники та 20 п'ятикурсників, які здобувають фах психолога. Формуючи вибірку зі студентів зазначених курсів, ми виходили з того, що процес становлення та зміни образу професійного «Я» у майбутніх психологів суттєво обумовлений формами і етапами навчання, тобто у процесі вузівського навчання уявлення про майбутню професію як структурний компонент професійної свідомості зазнають змін. Для реалізації мети дослідження було використано методики «Хто Я?» М. Куна і Т. Макпартленда та «Особисті професійні плани» Є. Клімова [2].

За методикою «Хто Я?» було отримано 708 самохарактеристик респондентів, 3 них 382 самохарактеристики було дано випускниками та 326 містилися у бланках першокурсників. Усі самохарактеристики були віднесені до однієї 3 трьох категорій: об'єктивні, професійні чи суб'єктивні. Особливості змісту образу «Я в професії» представлено на рисунку 1.

Як видно на рисунку 1 , курс навчання впливає на зміст уявлень про майбутню професію. Динаміка відзначається у зменшенні кількості об'єктивних самохарактеристик (з 47 \% на першому курсі до 35 \% на випускному) та збільшенні професійних (з 33 \% на першому до 37 \% на випускному) і суб'єктивних (з 21 \% до 29 \% відповідно). Отримані результати вказують на низький рівень сформованості професійної приналежності у студентів-психологів першого року навчання. Результати випускників демонструють вищий рівень професійної ідентичності, який відображений у ототожненні себе 3 категоріями «майбутній фахівець», «майбутній психолог», «практичний психолог», «психолог-консультант» тощо. 


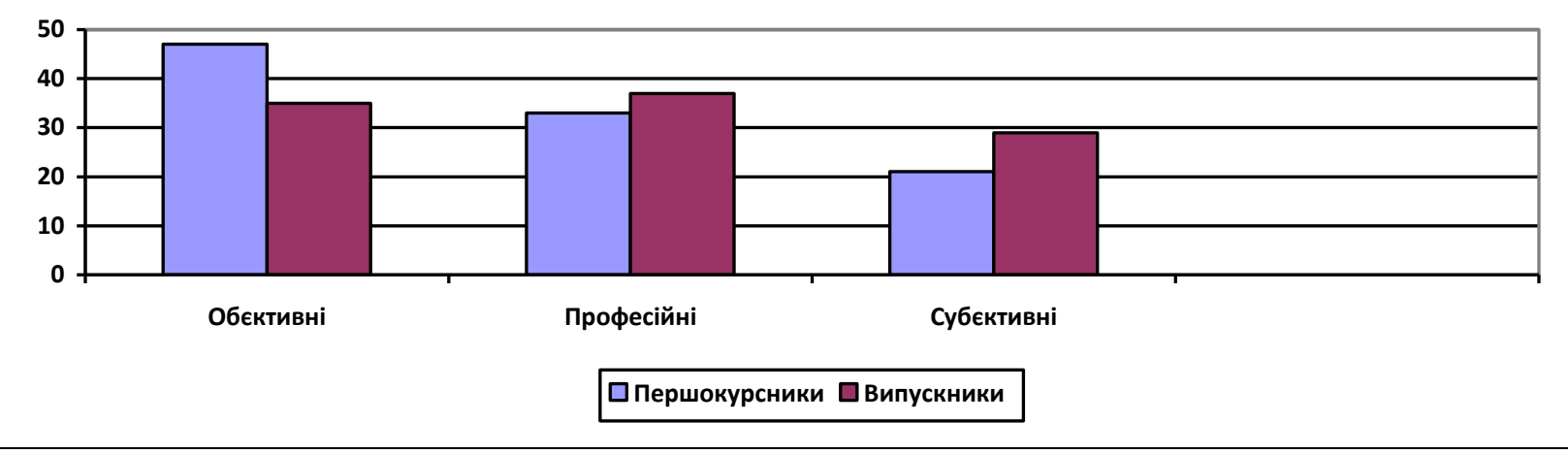

Pис. 1. Співвідномення компонентів змісту образу «Я в професії» (за методикою «Хто Я?»)

Для дослідження рівня сформованості у студентів уявлення про зміст діяльності, про ії об’єкт, мету та засоби, що є структурним компонентом уявлень про професію, ми використали методику «Особисті професійні плани» Є. Клімова. Узагальнені результати, отримані у ході дослідження, представлені на рис. 2. Найвищі кількісні показники у першокурсників отримано за шкалами «Головні професійні цілі» (86 \%), «Найближчі професійні цілі» $(81 \%)$.

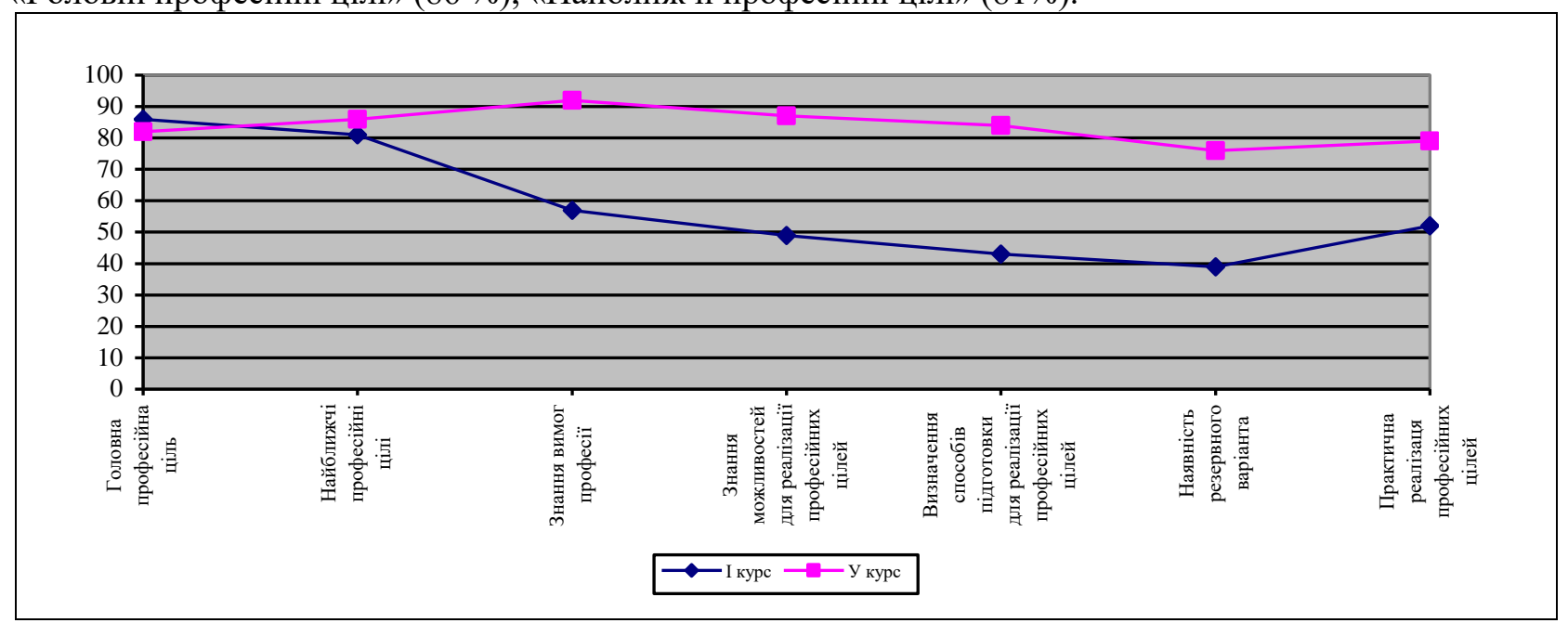

Pис. 2. Показники особистого професійного плану майбутніх психологів (у\%)

У своїх відповідях випускники відділи перевагу шкалам «Знання вимог професії до людини» (92 \%) і «Знання можливостей для реалізації професійних цілей» $(87 \%)$, за якими студенти першого курсу мають найнижчі показники (49\% та $43 \%$ відповідно). Отримані результати можна пояснити збільшенням обсягу інформації про майбутню спеціальність та накопиченням i засвоєнням професійних знань за період навчання. Наявність професійних знань зумовлює розширення спектру власних можливостей та їх усвідомлення, а наявність основної професійної мети створює відповідне підгрунтя для диференціації цілей, досягнення яких найближчим часом дасть змогу реалізувати головну професійну мрію у майбутньому. Таким чином, динаміка образу професії від першого до п’ятого курсу свідчить про тенденції до підвищення загального рівня професійної обізнаності, усвідомлення власних можливостей для досягнення поставлених цілей за період навчання у вузі. У той же час у першокурсників поряд із незначними показниками професійних знань спостерігається високий рівень особистої зацікавленості у отриманні відповідної інформації, у професійному спілкуванні і участі у різноманітних заходах психологічного спрямування, яку можна розглядати як передумову для досягнення професійної ідентичності у процесі подальшого навчання. Зростання кількості відповідей, що стосуються знання вимог професії, власних ресурсів та способів підготовки для досягнення поставлених цілей на випускному курсі свідчить про те, що тривалість та якість вузівського навчання є важливим чинником впливу на формування у студентів уявлень про обрану професію.

У ході емпіричного вивчення змісту уявлень студентів-психологів про обрану професію ми виявили, що під час вузівського навчання відбувається поступове формування їх структурних компонентів, а саме уявлень про суб'єкта професійної діяльності; уявлень про зміст діяльності, про ії 
об'єкт, мету та засоби; уявлень про себе як про майбутнього психолога. На процес розширення змісту професійної свідомості впливає тривалість навчання, творча, пізнавальна активність, теоретична і практична підготовка, розвиток саморефлексії і моделювання образів майбутньої професійної діяльності і себе у ній.

Аналіз отриманих результатів за методикою «Особисті професійні плани» Є. Клімова свідчить про те, що уявлення першокурсників про обрану професію ще нечіткі та ідеалізовані. Натомість більшість респондентів п'ятого курсу має чіткі уявлення щодо власних професійних цілей, вимог професії, власних ресурсів та способів підготовки для досягнення поставлених цілей.

Висновки та перспективи подальших досліджень. Найбільш об'ємним визначенням професійної належності є процес формування смислової системи, в якій поєднані уявлення про себе, світ і себе у професії. У формуванні професійної належності як засобу саморегуляції професійної діяльності слід визначити основні ії структурні елементи: усвідомлення професійної моралі, усвідомлення себе як суб'єкта професійної діяльності, усвідомлення і оцінка професійних стосунків, усвідомлення власного розвитку в часовому вимірі професійного усвідомлення. 3 урахуванням специфічності змісту професії психолога структуру уявлень про неї слід розглядати як трьохкомпонентну, де у якості основних елементів визначаються: уявлення про суб'єкта професійної діяльності; уявлення про зміст діяльності, іiі об'єкт, мету та засоби; уявлення про себе як про майбутнього психолога, зокрема, мотивація особистості на майбутнє займатися психологією.

У ході емпіричного дослідження було виявлено $9 \%$ студентів-першокурсників 3 відносною чіткими та стійкими уявленнями про себе. Зі збільшенням періоду навчання відсоток студентів зі сформованим професійним образом «Я» дещо підвищується, що, очевидно, обумовлено впливом професійної освіти та процесом особистісно-професійного зростання та саморозвитку. Отримані результати вказують на те, що тривалість та якість навчання у виші $є$ важливим чинником впливу на формування адекватного образу професії і уявлень про майбутню професію як його компонента в тому числі.

Перспективи подальших досліджень ми вбачаємо у пошуку ефективних психологічних впливів, спрямованих на розвиток підструктур професійної самосвідомості, а також створення відповідних психологічних умов для оптимізації процесу формування особистіснозрілого фахівця.

\section{Список використаних джерел}

1. Егорова И. А. Представления студентов о психологии как сфере будущей профессиональной деятельности [Электронный ресурс] / И. А. Егорова // Вестник Таганрогского института управления и экономики. Психология. - Режим доступа: https://cyberleninka.ru/article/n/predstavleniya-studentov-o-psihologii-kak-sfere-buduschey-professionalnoydeyatelnosti.

2. Климов Е. А. Психология профессионального самоопределения / Е. А. Климов - Москва : Академия, 2007. - 302 с.

3. Маркова А. К. Психология профессионализма / А. К. Маркова. - Москва: Междунар. гуманит. фонд «Знание», 1996. - $312 \mathrm{c.}$

4. Метельська Н. Й. Професійна самосвідомість майбутніх педагогів як складова їх професійного самовизначення / Н. Й. Мемельська // Психологія і особистість. - 2015. - № 2 (8). - С. 280-291.

5. Міхно К. О. Структура професійних уявлень та методи їх вивчення / К. О. Міхно // Вісник Київського національного університету імені Тараса Шевченка. Серія: Соціологія. Психологія. Педагогіка. - 2005. - № 22-23. - С. 85-88.

6. Семенова Е. А. Представления о профессии психолога у студентов заочной формы обучения [Электронный ресурс] / Е. А. Семенова // Альманах современной науки и образования. 2010. - № 3 (34), ч. 1. - С. 181-183. - Режим доступа : www.gramota.net/materials/1/2010/3- 1/56.html .

7. Туриніна О. Л. Психологічні особливості професійного самовизначення учнів профільних педкласів : дис. ... канд. психол. наук : 19.00.07 / О. Л. Туриніна. - Київ, 1997. - 218 с.

8. Шевченко Н. Ф. Становлення професійної свідомості практичних психологів у процесі фахової підготовки : монографія / Н. Ф. Шевченко. - Київ : Міленіум, 2005. - 298 с.

\section{References}

1. Egorova I. A. Predstavleniya studentov o psihologii kak sfere buduschey professionalnoy deyatelnosti [Elektronnyy resurs] / I. A. Egorova // Vestnik Taganrogskoho instituta upravleniya i ekonomiki. Psyhologiya. - Rezhim dostupa : https://cyberleninka.ru/article/n/predstavleniya-studentov-opsihologii-kak-sfere-buduschey-professionalnoy-deyatelnosti. 
2. Klimov E. A. Psihologiya professionalnogo samoopredeleniya / E. A. Klimov. - M. : Akademiya, 2007. $-302 \mathrm{~s}$.

3. Markova A. K. Psihologiya professionalizma / A. K. Markova. - M. : Mezhdunar. gumanit. fond «Znanie», 1996. - $312 \mathrm{~s}$.

4. Metelska N. I. Profesiina samosvidomist maibutnikh pedahohiv yak skladova yikh profesiinoho samovyznachennia / N. I. Metelska // Psykholohiya i osobystist. - 2015. - № 2 (8). - s. 280-291.

5. Mikhno K. O. Struktura profesiinykh uiavlen ta metody yikh vyvchennia / K. O. Mikhno // Visnyk Kyivskoho natsionalnoho universytetu imeni Tarasa Shevchenka. Seriia: Sotsiolohiia. Psykholohiia. Pedahohika. - 2005. - № 22-23. - S. 85-88.

6. Semenova E. A. Predstavleniya o professii psihologa u studentov zaochnoy formyi obucheniya [Elektronnyy resurs] / E. A. Semenova // Almanah sovremennoy nauki i obrazovaniya. - 2010. - № 3 (34), ch. 1. - S. 181-183. - Rezhim dostupa : www.gramota.net/materials/1/2010/3- /56.html.

7. Turynina O. L. Psykholohichni osoblyvosti profesiinoho samovyznachennia uchniv profilnykh pedklasiv : dis. ... kand. psikhol. nauk : 19.00.07 / O. L. Turynina. - Kyiv, 1997. - 218 s.

8. Shevchenko N. F. Stanovlennia profesiinoi svidomosti praktychnykh psykholohiv u protsesi fakhovoi pidhotovky : monohrafiya / N. F. Shevchenko. - Kyiv : Milenium, 2005. -298 s.

\section{O. Hlavinska, L. Novik REALIZATION OF PROFESSIONAL BELONGING FUTURE PSYCHOLOGISTS}

This study outlines the current issue of the future psychologists' readiness to vocational selfdetermination and career. It is well-known that the structure of vocational self-determination includes vocational activity, vocational self-consciousness, vocational self-regulation, and important vocational characteristics. Specialist vocational self-consciousness consists of career ideas, emotionally firm and rationally motivated attitude towards activities, other people, yourself, and surrounding at all. The author studies the phenomena of idea about the career as a personal, complicated, and practical mechanism that is an indicator of human experience, a component of vocational self-consciousness. Career idea is interpreted as a vocational constituent based on personal social ideas. These ones are principally developed as a result of individual ideas transformation, sets and social stereotypes towards specific kind of vocational activity. Among career ideas the author singles out such three interdependent structural components as the idea about personality as a specialist and about yourself as a coordinator of vocational activity; idea about the content and conditions, difficulties and tasks of vocational activity; idea about own career future. This paper provides the analysis of ideas about future psychologist career. The results demonstrate that career images and ideas do not appear by themselves. It is the product of personal self-cognition. Being influenced by vocational knowledge, skills, vocational readiness and adjustment, interpretation of the own possibilities, characteristics and distinctness of vocational role and coordinator of vocational activity these products can be transformed, filled up, expanded, and specified. The results revealed in the process of study show that it is necessary to conduct psychological influences focused on the development of self-consciousness vocational substructures and development of the appropriate psychological conditions to optimize the process of personally mature specialist formation in the context of studying at higher educational institutions.

Key words: vocational career, vocational self-determination, vocational consciousness, career idea, the future psychologists.

УДК 376

Н. З. ДЕРЕВ'ЯНКО

DOI: https://doi.org/10.35619/prap_rv.vi12.46

\section{РОЛЬ ІНКЛЮЗИВНОГО ОСВІТНЬОГО СЕРЕДОВИЩА ДЛЯ РОЗВИТКУ ПРОСОЦІАЛЬНОЇ ПОВЕДІНКИ ПІДЛІТКІВ}

У статті здійснено теоретичний аналіз понять «інклюзія», «інклюзивна освіта», «інклюзивне освітнє середовище», «просоиіальна поведінка». Розкрито тлумачення, принципи та засади інклюзивного освітнього середовища. Здійснено аналіз потенціалу інклюзивного освітнього середовища для розвитку просоиіальних поведінкових стратегій учасників освітнього прочесу. Зроблено припущення, що здорові діти в умовах інклюзивного навчання проявляють більще співчуття, співпереживання, розуміння, і допомоги один одному, що тим самим сприяє розвитку про соиіальних стратегій.

Ключові слова: інклюзія, освіта, інклюзивне навчання, інклюзивне освітнє середовище, просочіальна поведінка. 